\title{
Curcumin attenuates butter fat induced hyperlipidemia in mice
}

\section{Siddhartha Sarker, Md. Iqramul Haque, Khaled Mahmud Sujan, Maha Islam Talukder and $\bowtie$ Mohammad Alam Miah}

Department of Physiology, Bangladesh Agricultural University, Mymensingh-2202, Bangladesh

\begin{tabular}{l}
\hline ARTICLE INFO OPEN_Access \\
\hline Article history: \\
Received : 20 February 2019 \\
Accepted : 22 May 2019 \\
Published: 30 June 2019 \\
\hline Keywords: \\
Butter, Curcumin, lipid profile, \\
aorta and mice \\
Correspondence: \\
Mohammad Alam Miah \\
凶: alam.dina@ gmail.com
\end{tabular}

\begin{abstract}
Long-term intake of high-fat food disrupts lipid metabolism, resulting in fat accumulation, obesity, and hyperlipidemia. Curcumin, active ingredients of turmeric plants, has been shown to possess potent antioxidant and hypolipidemic properties. The study was conducted to observe the effects of curcumin on butter induced hyperlipidemia, hematological values and physio-pathological alterations in liver and aorta in mice. A total of 40 Swiss Albino mice (Mus musculus), aged 28-30 days with an average body weight of $27 \mathrm{~g}$ were randomly divided into 2 groups. Group A was considered as non-treated control (NT) (n=8) and fed on standard mice pellet and fresh drinking water. Another group was considered as butter group $(\mathrm{n}=32)$, fed on standard mice pellet enriched with $10 \%$ butter and after 5 weeks, mice of butter group were subdivided into 4 equal groups $(\mathrm{n}=8)$. Group $\mathrm{B}$ was considered as butter treated (BT) group fed on standard mice pellet enriched with $10 \%$ butter. Group C (C1\%), group D (C2\%) and group E (C3\%) fed on standard mice pellet enriched with $10 \%$ butter plus curcumin $1 \%, 2 \%$ and $3 \%$ in drinking water respectively. The experiment was carried out for period of another 10 weeks. Body weight gain of all mice was gradually increased and maximum weight gain was recorded in mice of butter fed group. Supplementation of curcumin to butter treated mice (group C, D and E) prevented weight gain. Mice treated with butter fat had significantly $(\mathrm{p}<0.01)$ higher hemoglobin $(\mathrm{Hb})$ concentration, total erythrocyte count (TEC) and packed cell volume (PCV). Treatment with curcumin of $1 \%, 2 \%$, and $3 \%$ concentration on butter supplemented mice didn't alter or rather enhanced the hematological values. In case of lipid profile, supplementation of butter fat in feed significantly increased the total cholesterol, triglycerides and LDL cholesterol. However, addition of curcumin extracts of $1 \%, 2 \%$ and $3 \%$ concentration to the butter fed group mice dramatically reduced the total cholesterol and LDL-cholesterol values and more prominent result was observed in $2 \%$ curcumin treated mice. Histo-pathological studies of liver and aorta revealed that addition of $10 \%$ butter to feed induced a few fatty changes along with pyknotic nuceli in the hepatocytes, thickened wall of aorta with disorganized lining cells. Again upon curcumin treatment, no such changes were detected in the liver and aortic tissues of group C, group D and group E. Our study revealed that the butter fats have harmful effects on weight gain, on lipid profile and on organ structures without deteriorating normal hematological values. However, these harmful effects could be mitigated by addition of curcumin extracts.
\end{abstract}

Copyright:

(c) (i)

(C2019 by authors and BAURES. This work is licensed under the Creative Commons Attribution International License (CC By 4.0).

\section{Introduction}

Hyperlipidemia is a common disorder caused by life style habits in developed countries and is the major cause of coronary heart disease (CHD). It results from abnormalities in lipid metabolism or plasma lipid transport or a disorder in the synthesis and degradation of plasma lipoproteins (Jang et al., 2008). The consequence of hyperlipidemia can cause atherosclerosis, and thus the risk of coronary heart disease and stroke is increased. Diabetes mellitus is associated with hyperlipidemia, which is a significant risk factor for cardiovascular diseases (El- Moselhy et al., 2011). An abnormal accumulation of fat in the liver and muscle elicits insulin resistances that culminate in beta cell reduction in type 2 diabetes (Seo et al., 2008).

The epidemiological studies showed that the consumption of fat rich diet and the animal source derived food products are appropriate key factor for
CHD and known cause of death all over the world (Rajendran and Ekambaram, 2010). The risk factors of CHD may include age, sex, obesity, diabetes, increased blood cholesterol, triglycerol (TAG), and lipoproteins such as LDL (Nago et al., 2011). Increased levels of serum total cholesterol, triglycerides, very low density lipoproteins (VLDLs), low density lipoproteins (LDLs) and decreased levels of high density lipoproteins cholesterol (HDL-c) in blood is referred as hyperlipidemia (Javed et al., 2006). Cardiovascular disease (CVD) is the foremost cause of deaths in South Asia (Lim et al., 2012).

Preventing the epidemic of obesity becomes one of the greatest public health challenges in the first half 21 st century. It is a predisposing factor for many adverse health outcomes like non-insulin dependent diabetes mellitus (NIDDM), insulin resistance, atherosclerosis, dyslipidemia and cardiovascular diseases. Obesity 
results from a positive energy balance that is, when caloric intake chronically exceeds energy expenditure. The current environmental risk factors include over consumption of energy (increase in fat to carbohydrate ratio) and decrease in physical activity. Intake of high lipid or fat containing food is of prime importance for obesity leading to cardiovascular diseases. These factors offer more reasonable explanation for the recent dramatic surge in the prevalence of obesity (Kalaivanisailaja et al., 2008).

About $80 \%$ of world's population depends on indigenous medicinal plants and $61 \%$ of global population has been reported to use herbal therapy in various diseased conditions. Use of indigenous plants as remedy against various diseases is increasing because synthetic drugs possess many side effects (Javed et al., 2009). There are certain cholesterol lowering functional foods and extracts of traditional plants which are getting more and more attention these days. Such type of foods and plant extracts are possibly alternative therapy for treating the hypercholesterolemia patients whose blood cholesterol level is slightly raised rather, in treating the patients having very high cholesterol level and cardiovascular diseases (Chen et al., 2008; Grundemann et al., 2011). High fat diet (HFD) is associated with oxidative stress induced fatty liver.

Curcumin is an extract of turmeric plants (Curcuma Longa). It has been shown to possess potent antioxidant and hypolipidemic properties (Oneriyidogan et al., 2014), reduces inflammation, atherosclerosis, and obesity in several animal studies. In mice fed, a high-fat diet (HFD), curcumin reduces plasma lipid levels (Zingg et al., 2017). Curcumin prevented the highfructose induced hyperlipidemia and hepatic steatosis. (Maithilikarpagaselvi et al., 2016). It affects lipid metabolism and subsequently may alleviate hyperlipidemia and atherosclerosis. Plasma HDL cholesterol (HDL-C) is an independent negative risk predictor of cardiovascular disease (CVD). However, numerous clinical and genetic studies have yielded disappointing results about the therapeutic benefit of raising plasma HDL-C levels. Curcumin may subsequently improve conditions in which HDL is dysfunctional and may have potential as a therapeutic drug in future (Ganjali et al., 2017). Curcumin is also widely used to color many foods (CTA). Further, it has been widely used in traditional medicine in Southeast Asia. It prevents many diseases including biliary disorders, anorexia, cough, diabetes, hepatic disorders, rheumatism, sinusitis, cancer, and Alzheimer's (Aggarwal and Harikumar, 2009).

In connection of that, this present study was designed to investigate the hypolipidemic effects of curcumin extracts on hyperlipidemia mouse model fed with a high-fat diet. The laboratory animals (mice, rats) are alternative choice worldwide as an experimental model. Hence, this study was conducted to detect the effects of curcumin on butter induced hyperlipidemia, hematological parameters and physio-pathological alterations in liver and aorta in mice.

\section{Materials and Methods}

\section{Experimental animals}

The experiment was conducted in the Department of Physiology, Bangladesh Agricultural University (BAU), Mymensingh. A total of forty Swiss Albino mice (Mus musculus), age of 28-30 days with an average body weight of $27 \mathrm{~g}$ were used. At first, the mice were randomly divided into 2 groups. Group A was considered as control (NT) $(n=8)$ and fed on standard mice pellet and fresh drinking water. Another group of mice was considered as butter group (BT) $(n=32)$, fed on standard mice pellet enriched with $10 \%$ butter for 5 weeks and after 5 weeks, mice of butter group were subdivided into 4 groups each containing 8 mice. Group B was continued as butter group fed on standard mice pellet enriched with $10 \%$ butter as usual whereas group $\mathrm{C}(\mathrm{C} 1 \%)$, group D (C2\%), and group E ( $\mathrm{C} 3 \%)$ fed on standard mice pellet enriched with $10 \%$ butter plus curcumin $1 \%, 2 \%$, and $3 \%$ in drinking water respectively. The experiment was carried out for period of another 10 weeks.

\section{Preparation of curcumin extracts}

The preparation of curcumin extracts were made by the method described by Gokhul et al,. 2015 with slight modifications. The fresh rhizomes of Curcuma longa Linn. were obtained from local markets (Kawatkhali) in Mymensingh. All rhizome samples were cleaned, cut, air dried and then grinded into powder by using mortar. Since curcumin is soluble in ethanol, the powder was soaked in 99\% ethanol (1:4) into an air-tight container (molecular biology grade, Merck, Germany) for two to three days and were kept in a dark place. Then the solution was filtered to remove the solid particles. This liquid solution contained curcumin. Then the volume of solution was gradually reduced by pouring it into a sterile wide tray and the solution was further letting stand until most of the ethanol in the solution had evaporated. It looked something of a gummy mess, which is enriched in curcumin. 1\%, 2\% and 3\% curcumin extracts were prepared by adding 1,2 and $3 \mathrm{ml}$ of curcumin extracts (gummy mess) into 99, 98 and 97 $\mathrm{ml}$ of distilled water respectively (Gokhul et al., 2015).

\section{Management practices}

The mouse cages were kept on a well-ventilated room. In order to prevent spoilage, feeds were kept in air tight poly packed sac. The feed was supplied daily to the mice and fresh drinking water was made available. Mice cage were cleaned regularly and proper hygienic and sanitary measures were also adopted during entire experimental period. Feces were removed regularly. 


\section{Body weight}

Initial body weight of each mouse was measured with the help of an electric balance. Body weight was taken at 0 day and then 15 days intervals until end of experiments. Body weight gain was calculated as weight gain $(\mathrm{g})=$ mean final body weight $(\mathrm{g})$ minus mean initial weight (g). Percent body weight gain was calculated as percent weight gain $(\mathrm{g})$ equal to mean final weight $(\mathrm{g})$ minus mean initial weight $(\mathrm{g})$ divide by mean initial weight $X 100$

\section{Hematological studies}

Blood samples were collected by cardiac puncture. The mice were kept fasting overnight. Then the mice were placed an airtight container one by one containing diethyl ether presoaked cotton. The unconscious mice were taken out and the blood was collected directly from heart by a sterile syringe. About $1.5 \mathrm{ml}$ blood was collected and transferred half of blood into anticoagulant containing eppendorf tube and the remaining half of blood was transferred to another tube without anticoagulant for serum preparation. The blood containing tubes were placed in upright slanting position at room temperature for 6 hours. They were then incubated overnight in the refrigerator $\left(4^{\circ} \mathrm{C}\right)$. The serum samples were separated by centrifugation and collected by using $200 \mu \mathrm{l}$ pipette. Serum samples were stored in capped tube at $-20^{\circ} \mathrm{C}$ for biochemical analysis. TEC, $\mathrm{Hb}$ concentration and PCV were determined according to procedure described by Ghai, 1999.

\section{Serum biochemical studies}

The lipid profile like total serum cholesterol, triglycerides, HDL cholesterol and LDL cholesterol were performed colorimetrically using Humalyzer 2000 (Human type, Germany) following instructions provided by Tinder (1969).

\section{Histopathology}

The liver and aorta from each group of mice were collected after complete removal of blood by perfusion with phosphate buffered saline and kept in $10 \%$ neutral buffered formalin for 15 days. The well- fixed tissues were processed, sectioned and stained as per standard procedure (Luna, 1968) in collaboration with the Department of Pathology, Bangladesh Agricultural University, Mymensingh.

\section{Statistical analysis}

All data were subjected to statistical analysis using oneway ANOVA with post-hoc Turkey's test as per Steel and Torrie, (1980). Statistical analysis was performed using Graph Pad Prism 7 software.

\section{Results and Discussion}

\section{Body weight}

Body weights and body weight gain in mice of butter and normal healthy control were recorded weekly and the body weight and percentage of body weight gain after 5 weeks of experiment is shown in Table 1. Body weight of all mice gradually increased and maximum weight gain was noticed in mice of butter fed group after 5 weeks of experiment. All butter supplemented mice had increased weight gain than those of non-butter treatment group Table 1. Hoefel et al. (2011) stated that consumption of high fat diets is strongly and positively associated with overweight and obesity. Cho et al. (2012) also reported that consumption of high fat diet induces excessive weight gain. All these reports are similar to our current findings. After 5 weeks of experiment, mice of butter group were subdivided into four groups and three groups were supplemented with $1 \%, 2 \%$, and $3 \%$ of curcumin extracts respectively in drinking water daily along with butter supplementation for 10 weeks. We observed addition of curcumin extracts to butter treated mice prevented butter induced weight gain. That means curcumin extracts significantly prevented the excess weight gain induced by high fat diet (butter) and maximum weight gain was noticed in mice of butter fed group (Table 2).

Table 1. Comparison of average body weight gain at 5 th week of experiments in two treatment groups

\begin{tabular}{lcccc}
\hline $\begin{array}{c}\text { Treatment } \\
\text { groups }\end{array}$ & $\begin{array}{c}\text { Initial body weight } \\
(\mathrm{g})\end{array}$ & $\begin{array}{c}\text { Body weight at 5th } \\
\text { week }(\mathrm{g})\end{array}$ & $\begin{array}{c}\text { Body weight gain after 5 } \\
\text { weeks }(\mathrm{g})\end{array}$ & $\begin{array}{c}\text { Body weight gain after } \\
5 \text { weeks }(\%)\end{array}$ \\
\hline Control & $27.23 \pm 2.2$ & $38.74 \pm 2.9$ & $11.47 \pm 3.58$ & 42.12 \\
Butter & $27.22 \pm 3.1$ & $46.7 \pm 2.67$ & $19 . .97 \pm 4.19$ & 71.86 \\
\hline
\end{tabular}

Table 2. Comparison of body weight and percentage of body weight

\begin{tabular}{lcccc}
\hline Treatment group & \multicolumn{3}{c}{ Body weight (Mean \pm SD ) $(\mathrm{g})$} & \multirow{2}{*}{$\%$ gain at 15th week } \\
\cline { 2 - 4 } & $5^{\text {th }}$ week & $10^{\text {th }}$ week & $15^{\text {th }}$ week & 61.58 \\
Group A (Control) & $38.70 \pm 2.50$ & $43.40 \pm 2.25$ & $44.00 \pm 2.27$ & 105.65 \\
Group B (butter) & $46.77 \pm 2.57$ & $52.15 \pm 1.12$ & $56.12 \pm 1.40$ & 89.27 \\
Group C (C1\%) & $47.36 \pm 2.69$ & $50.15 \pm 1.75$ & $51.54 \pm 1.49$ & 75.02 \\
Group D (C2\%) & $47.86 \pm 2.65$ & $49.25 \pm 1.50$ & $47.66 \pm 1.95$ & 78.69 \\
Group E (C3\%) & $46.26 \pm 3.57$ & $50.25 \pm 1.50$ & $48.66 \pm 2.22$ & \\
\hline
\end{tabular}


Hematological parameters:

Total erythrocyte count (TEC) and hemoglobin concentration (Hb conc.) and packed cell volume (PCV) in different treated groups of mice were analyzed after 15 weeks of experiments and results are presented in Table 3. Mice treated with butter fat had significantly $(\mathrm{p}<0.01)$ higher blood parameters except hemoglobin concentration: hemoglobin $(\mathrm{Hb})$ concentration $(6.70 \pm$ $0.53 \mathrm{~g} \mathrm{\%}$ ), total erythrocyte count (TEC) $(6.63 \pm 0.05$ million $/ \mu \mathrm{L}$ ) and packed cell volume (PCV) (36.33 \pm $1.53 \%)$ compared with those parameters (Hb concentration $6.23 \pm 0.91 \mathrm{~g} \%$, TEC $4.25 \pm 1.35$ million / $\mu \mathrm{L}$ and PCV $34.33 \pm 1.53 \mathrm{~g} \%)$ of non-treated control mice (Table 3). Interestingly, addition of curcumin extracts on butter supplemented mice rather significantly improved the hematological values (group $\mathrm{C}: \mathrm{Hb}$ concentration $7.40 \pm 0.20 \mathrm{~g} \%$, TEC $6.21 \pm 0.21$ million $/ \mu \mathrm{L}$ and $\mathrm{PCV} 39.67 \pm 1.53 \%$ and group $\mathrm{D}: \mathrm{Hb}$ concentration $7.93 \pm 0.31 \mathrm{~g} \%$, TEC $6.37 \pm 0.41$ million / $\mu \mathrm{L}$ and $\mathrm{PCV} 38.00 \pm 2.65 \%$ and group $\mathrm{E}: \mathrm{Hb}$ concentration $8.00 \pm 0.72 \mathrm{~g} \%$, TEC $6.28 \pm 1.15$ million / $\mu \mathrm{L}$ and PCV $40.67 \pm 3.06 \%$ respectively (Table 3 ). Similar results were reported by Ekanem and Yusuf (2008) who found significantly increased hemoglobin concentration and red cell counts of fat treated mice when compared to the untreated ones.

\section{Lipid profile:}

The effect of butter and curcumin on lipid profile is shown in Table 4. Obtained results revealed that addition of butter in feed significantly increased the total cholesterol values in group-B $(259.10 \pm 11.23 \mathrm{mg} / \mathrm{dL})$, triglycerides $(212.00 \pm 12.58 \mathrm{mg} / \mathrm{dL})$, HDL (54.39 \pm $2.53 \mathrm{mg} / \mathrm{dL})$, LDL $(153.57 \pm 9.64 \mathrm{mg} / \mathrm{dL})$, values compared to the values of non-treated control mice (Table 4). Our findings were quite similar to that of previously reported data showing increased cholesterol and triglycerides levels in animals with addition of butter compared to those values of control group (Khairy et al., 2014; Alaam et al., 2012). However, addition of curcumin extracts of either $1 \%, 2 \%$ or $3 \%$ concentration to the butter fed group mice significantly reduced the total cholesterol, LDL-cholesterol values compared to the values of butter fed group (Table 4). In addition, a significant increase in HDL level was observed in curcumin treated groups $(\mathrm{C}, \mathrm{D}$ and $\mathrm{E})$ compared to groups (A and $\mathrm{B}$ ) with the highest value in group-E $(65.33 \pm 1.53 \mathrm{mg} / \mathrm{dL})$.

Effect on butter and curcumin extracts on physiopathological alterations in liver and aorta

Excess lipids (cholesterols and triglyceride) are gradually deposited in the wall of aorta and liver leading to atherosclerosis and fatty liver syndromes. We found raised cholesterol and triglycerides values in butter fed mice and those values were reduced upon addition of curcumin extracts (Table 4). To know whether fat could deposit in the wall of aorta and liver after 15 weeks of experiment, tissue histology on liver and aorta were performed.

Table 3. Effects of butter supplementation and curcumin treatments on blood parameters in mice at 15th week

\begin{tabular}{cccccc}
\hline Parameters & \multicolumn{5}{c}{ Mean \pm SD } \\
\cline { 2 - 6 } & Group-A (NT) & Group-B (BT) & Group-C (C1\%) & Group-D (C2\%) & $\begin{array}{c}\text { Group-E } \\
(\text { C3\% })\end{array}$ \\
\hline Hb (g \%) & $6.23 \pm 0.91^{\mathrm{c}}$ & $6.70 \pm 0.53^{\mathrm{c}}$ & $7.40 \pm 0.20^{\mathrm{b}}$ & $7.93 \pm 0.31^{\mathrm{ab}}$ & $8.00 \pm 0.72^{\mathrm{ab}}$ \\
TEC (million/ $/ \mathrm{L})$ & $4.25 \pm 1.35^{\mathrm{b}}$ & $6.63 \pm 0.05^{\mathrm{a}}$ & $6.21 \pm 0.21^{\mathrm{a}}$ & $6.37 \pm 0.41^{\mathrm{a}}$ & $6.28 \pm 1.15^{\mathrm{a}}$ \\
PCV (\%) & $34.33 \pm 1.53^{\mathrm{c}}$ & $36.33 \pm 1.53^{\mathrm{bc}}$ & $39.67 \pm 1.53^{\mathrm{ab}}$ & $38.00 \pm 2.65^{\mathrm{abc}}$ & $40.67 \pm 3.06^{\mathrm{a}}$ \\
\hline
\end{tabular}

Values with different letters in a column differs significantly $(\mathrm{P}<0.05)$

Table 4. Effects of butter supplementation and curcumin treatments on lipid profile in mice at 15th week

\begin{tabular}{llllll}
\hline \multicolumn{1}{c}{ Biochemical } & \multicolumn{5}{c}{ Mean \pm SD } \\
\cline { 2 - 6 } Parameters & Group-A (NT) & Group-B (BT) & Group-C (C1\%) & Group-D (C2\%) & Group-E (C3\%) \\
\hline Cholesterol (mg/dL) $_{\text {Triglycerides (mg/dL) }}$ & $202.00 \pm 11.00^{\mathrm{bc}}$ & $259.10 \pm 11.23^{\mathrm{a}}$ & $181.67 \pm 10.41^{\mathrm{cd}}$ & $176.009 .64^{\mathrm{d}}$ & $201.67 \pm 7.64^{\mathrm{b}}$ \\
HDL (mg/dL) & $52.67 \pm 3.52^{\mathrm{d}}$ & $212.00 \pm 12.58^{\mathrm{b}}$ & $190.00 \pm 17.32^{\mathrm{ab}}$ & $166.67 \pm 7.64^{\mathrm{cd}}$ & $186.00 \pm 10.00^{\mathrm{ab}}$ \\
LDL $(\mathrm{mg} / \mathrm{dL})$ & $54.39 \pm 2.53^{\mathrm{b}}$ & $57.33 \pm 6.43^{\mathrm{b}}$ & $61.67 \pm 1.53^{\mathrm{c}}$ & $65.33 \pm 1.53^{\mathrm{a}}$ \\
\hline
\end{tabular}

Values with different letters in a column differs significantly $(\mathrm{P}<0.05)$.

Section of liver of control group showed normal tissue structures and no detectable changes were found in tissues whereas, butter fed group revealed little fatty changes along with pyknotic nuclei of hepatocytes. However, upon curcumin treatment we could not detect any fat deposition in liver of group C, group D and group E.
Section of aorta of non-treated mice showed normal tissue structures and no remarkable changes were found in aortic tissues of other treated mice after 15 weeks of study. Although there was little thickening of the aorta and disarrangement of lining cells of the aorta found in butter treated group. Again in curcumin treated groups were not able to observe any changes in the tissues of group $\mathrm{C}$, group $\mathrm{D}$ and group $\mathrm{E}$. 


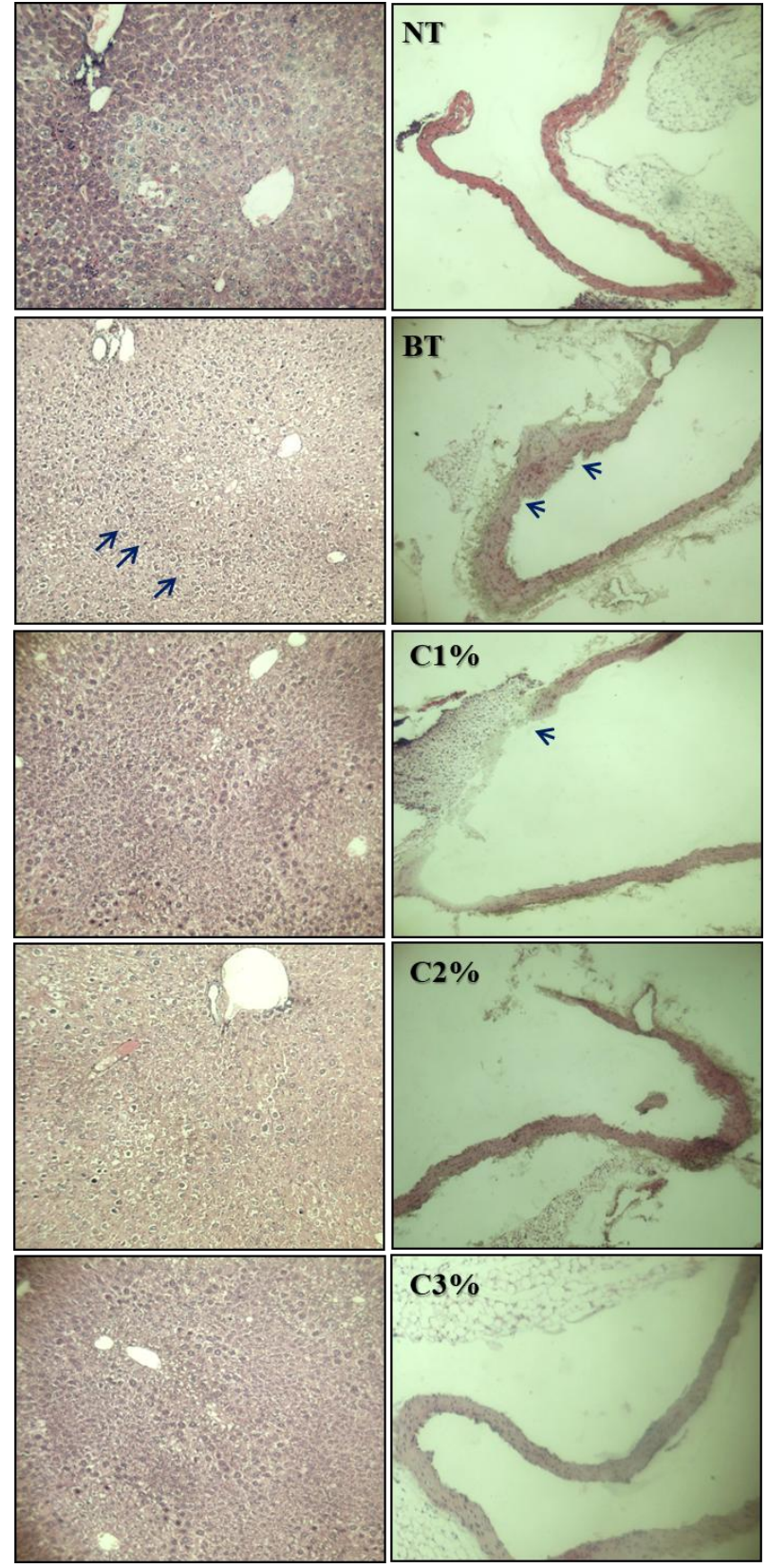

Fig. 4. Effects of curcumin on histopathological changes in liver and aorta of butter fed mice

(A) Photomicrograph $(100 \mathrm{X})$ of histopathological sections of liver tissues of different group of mice at $15^{\text {th }}$ week of experiment.

(B) Photomicrograph (100X) of histopathological sections of aortic tissues of different group of mice at $15^{\text {th }}$ week of experiment.

\section{Conclusion and Future Remarks}

Based on the results of this study, it can be concluded that butter fats have harmful effects on weight gain, on lipid profile and on organ structures with minimum alteration of hematological values. Curcumin extracts have the potential to eliminate such harmful effects. However, the concentration of curcumin was not determined in this study; therefore it is necessary to know exact concentration of curcumin effective for the alleviation of fat induced physiological changes. Further concise studies is needed with known concentration of curcumin extracts to fill up the laps and gaps of the present research.

\section{Acknowledgement}

This research work was funded by Ministry of Science and Technology, Government of the People's Republic of Bangladesh (MoST: 2016-2017, BS-40).

\section{References}

Aggarwal, B.B. and Harikumar, K.B. 2009. Potential therapeutic effects of curcumin, the anti- inflammatory agent, against neurodegenerative, cardiovascular, pulmonary, metabolic, autoimmune and neoplastic diseases. International Journal of Biochemistry and Cell Biology. 41: 40-59. https://doi.org/10.1016/j.biocel.2008.06.010.

Alaam, M.H., Yasin, N.M.N., Hafez, S.A., and Mohammed, H.H..I 2012. Biological and histological evaluations of palm oil and its fractions. World journal of Dairy \& Food Sciences. 7 (2): 120-130.

Chen, Z.Y., Jiao, R. and Ma, K.Y. 2008. Cholesterol-lowering nutraceuticals and functional foods. Journal of Agricultural Food Chemistry. 56: 8761-8773. https://doi.org/10.1021/jf801566r

Cho, S,J., Jung, U,J., and Choi, M,S., 2012. Differential effects of lowdose resveratrol on adiposity and hepatic steatosis in dietinduced obese mice. The British Journal of Nutrition, 108: 2166-75. https://doi.org/10.1017/S0007114512000347

Ekanam, J,T., and Yusuf, O,K., 2008. Some biochemical and hematological effects of black seed (Nigella sativa) oil on Trypanosomabrucei infected rats. African Journal of Biotechnology, 7(2): 153-157.

El-Moselhy, M,A., Taye, A., Sharkawi, S,S., El-Sisi, S,F,I., Ahmed, A,F., 2011. The antihyperglycemic effect of curcumin in high fat diet fed rats. Role of TNF- $\alpha$ and free fatty acids. Food and Chemical Toxicology, 49: $1129-1140$. https://doi.org/10.1016/j.fct.2011.02.004

Ganjali, S., Blesso, C,N., Banach, M., Pirro, M., Majeed, M., Sahebkar, A., 2017. Effects of curcumin on HDL functionality. Pharmacological Research, 119: 208-218. https://doi.org/10.1016/j.phrs.2017.02.008

Ghai, C,L., 1999. A text book of Practical Physiology. $7^{\text {th }}$ Edition, Jaypee Brothers Medical Publishers (p) Ltd, New Delhi.

Gokhul, V., Yuvapriya, S., Chandramohan, M., and Muthukumaran, P., 2015. Isolation and extraction of curcumin from three different varieties of Curcuma Longa L - A Comparative Study. International Journal of Pharmaceutical Research \& Allied Sciences, 79-84.

Grundemann, C., Papagiannopoulos, M., Lamy, E., MerschSundermann, V., and Huber, R., 2011. Immunomodulatory properties of a lemonquincepreparation as an indicator of anti-allergicpotency. Phytomedicine, 18: 760-768. https://doi.org/10.1016/j.phymed.2010.11.016

Hoefel, A,L., Hansen, F., Rosa, P,D., Assis, A,M., Silveira, S,L., Denardin, C,C., Pettenuzzo, L., Augusti, P,R., Somacal, S., Emanuelli, T., Perry, M,L., and Wannmacher, C,M., 2011. The effects of hypercaloric diets on glucose homeostasis in the rat: influence of saturated and monounsaturated dietary lipids. Cell Biochemistry and Function, 29: 569-76. https://doi.org/10.1002/cbf.1789

Jang, E,M., Choi, M,S., Jung, U,J., Kim, M,J., Kim, H,J., Jeon, S,M., Shin, S,K., Seong, C,N., Lee, M,K., 2008. Beneficial effects of curcumin on hyperlipidemia and insulin resistance in high-fat-fed hamsters.Metabolism Clinical and Experimental, 57: 1576 -1583. https://doi.org/10.1016/j.metabol.2008.06.014

Javed, I., Iqbal, Z., Rahman, Z,U., Khan, F,H., Muhammad, F., Aslam, B., and Ali, L., 2006. Comparative antihyperlipidaemic efficacy of Trychyspermumammi extracts in albino rabbits. Pakistan Veterinary Journal, 26: 23-29.

Javed, I., Rahman, Z,U., Khan, M,Z., Muhammad, F., Aslam, B., Iqbal, Z., Sultan, J,I., and Ahmad, I., 2009. Antihyperlipidaemic 
efficacy of Trachyspermumammi in albino rabbits. Acta Veterinary Brno, 78: 229-236. https://doi.org/10.2754/avb200978020229

Kalaivanisailaja, J., Manju, V., Nalini, N., 2008. Lipid profile in mice fed a high-fat diet after exogenous leptin administration. Poland Journal of Pharmacology, 55: 763-769.

Khairy, M,S,M., Galal, S,M., El-Rahman, M,K., and Katry, M,A., 2014. Palm kernel oil increases the risk of coronary heart disease in rats compared with ghee. IOSR Journal of Pharmacy and Biological Sciences, 9:34-40. https://doi.org/10.9790/3008-09163440

Lim, S,S., Vos, T., Flaxman, A,D., Danaei, G., Shibuya, K., 2012. A comparative risk assessment of burden of disease and injury attributable to 67 risk factors and risk factor clusters in 21regions, 1990-2010: a systematic analysis for the global burden of disease study 2010. Lancet, 380: 2224-2260

Luna L,G., 1968. Manual of histopathologic staining methods of the Armed Forces Institute of Pathology. $3^{\text {rd }}$ edition. McGrawHill book company, London.

Maithilikarpagaselvi, N., Sridhar, M,G., Swaminathan, R,P., Sripradha, R., Badhe, B., 2016. Curcumin inhibits hyperlipidemia and hepatic fat accumulation in high-fructose-fed male Wistar rats. Pharmaceutical Biology, 54:12, 2857-2863. https://doi.org/10.1080/13880209.2016.1187179

Nago, N., Ishikawa, S., Goto, T., and Kayaba, K., 2011. Low cholesterol is associated with mortality from stroke, heart disease, and cancer: the Jichi Medical School Cohort Study. Journal of Epidemiology, 21: 67-74. https://doi.org/10.2188/jea.JE20100065
Oneriyidogan, Y., Tanrikulu-Kucuk, S., Seyithanoglu, M., Kocak, H., DogruAbbasoglu, S., Aydin, A,F., Beyhan-Ozdas, S., Yapislar, H., KocakToker, N,. 2014. Effect of curcumin on hepatic hemeoxygenase 1 expression in high fat diet fed rats: is there a triangular relationship? Canadian Journal of Physiology and Pharmacology, 92(10): 805-812. https://doi.org/10.1139/cjpp-2014-0174

Rajendran, R., and Krishnakumar, E., 2010. Hypolipidaemic activity of chloroform extract of Mimosa pudica leaves. Avicenna Journal of Medical Biotechnology, 2: 215-221.

Seo, K,I., Choi, M,S., Jung, U,J., Kim, H,J., Yeo, J., Jeon, S,M., and Lee, M,K., 2008. Effect of curcumin supplementation on blood glucose, plasma insulin, and glucose homeostasis related enzyme activities in diabetic $\mathrm{db} / \mathrm{db}$ mice. Molecular Nutrition and Food Research, 52: 1- 10. https://doi.org/10.1002/mnfr.200700184

Steel, R,G,D., and Torrie, J,H., 1980. Principles and Procedures of Statistics, A biometrical approach. $2^{\text {nd }}$ edition. McGrawHill, New York, USA, pp. 20-90.

Tinder, P., 1969. Cholesterol Determination Test. Clinical Biochemistry, 6: 24-25

Zingg, J,M., Hasan, S,T., Nakagawa, K., Canepa, E., Ricciarelli, R., Villacorta, L., Azzi, A., and Meydani, M., 2017. Modulation of cAMP levels by high-fat diet and curcumin and regulatory effects on CD36/FAT scavenger receptor/fatty acids transporter gene expression. Biofactors, 43(1):42-53. https://doi.org/10.1002/biof.1307 